\title{
Promotion of Project-Based Learning Aimed at Professional Skills*
}

\author{
LIU Li, GAO Ying \\ Dalian University of Technology, Dalian, China
}

\begin{abstract}
Project-based learning theory is applied in Software English course. The aim is to develop students' professional skill. A professional skill scale of software engineer is introduced with Software English communicative skill (reading skill, writing skill, listening skill, and communicative skill), engineering thinking habit (skill of design the plan and problem-solving skill), engineering thinking skill, knowledge of software engineering, and Emotion Quotient to deal with problems (Team spirit and communicative skill and self-assessment skill). For software majors, students learn about five stages and job responsibilities in software making process.
\end{abstract}

Keywords: project-based learning, professional skill scale, Software English, EOP

\section{Introduction}

With the expanding of great needs for the improvement of professional skill, EOP (English for Occupational Purposes) course is gaining more popularity. Our department is Software Department and students should participate in EOP programs after one year of English learning. EOP practitioners realize the importance of switching the focus of EOP programs with futile attempts to fulfill content-focused goals, for instructors feel that "too much" teaching through content-area materials infringes on their own domain of expertise and trivializes their own contribution to the joint project (Coleman, 1983). Two years of project-based learning experience provide us with the possibility to explore more practical ways to improve students' professional skill which turns out to be the focus of EOP programs and is regarded as one of the best choices by us.

\section{Need Analysis in EOP Training}

Currently, students are facing the challenge to meet a need related to employment. Chinese universities are shifting focus from general English to English for specific purpose, implementing a career-oriented English course in the chosen professional field. The essence of teaching English for professional purposes means that

\footnotetext{
* Acknowledgements: Dalian University of Technology Graduation Teaching Project: Application Multimodal English Presentation Videos in Graduates Courses in Mobile Learning Environment; Dalian University of Technology Teaching Materials Project: International Business Letters; Dalian University of Technology Basic Professional Work Project: Project-Based Learning in ESP Flipped Classroom and Output Ability Cultivation; Liaoning Social and Economic Research Project: Construction of Software English Teaching Materials Based on Requirement of Positions and PjBL Designing Ideas; Liaoning Province Foreign Language Teaching Project: ESP Course System Construction and Teaching Research Based on Requirement of Positions and Project-Based Learning; Dalian Basic Professional Work Project: Research of Communicative Function of Gesture Based on Spoken Multimodal Language Corpus (DUT15RW135); Liaoning Province Social Science Planning Project: Comparison Study onthe Non-verbal Communication Behavior in Multimodal Utterance Within Ecological Language Frame (L13DYY036).

LIU Li, lecturer, master, Software Department, Dalian University of Technology.

GAO Ying, associate professor, master, Software Department, Dalian University of Technology.
} 
the department is to meet the aspirations of our students to continue their education in a different cultural environment or to seek employment there (Millrood, 2014).

Over the past two years, we have been involved as software English program developers, curriculum planners, and instructors in EOP course for software engineer students. This professional skill-focused program began as an adjunct to the EFL (English as a Foreign Language) program curriculum. Currently, it has become an independent program and evolved into a project-based learning approach.

Need analysis is seen as one of the defining characteristics of ESP (English for Specific Purposes) and key to planning both ESP curricula and classroom activities (Yogman \& Kaylani, 1996). In order to respond to the specific needs of software engineers in talent market, our department launched a practical EOP training program (a branch of ESP program) in September. EOP teachers were funded with RMB10,000 to engage in academic activities which enhanced their status and the prestige of the discipline. In the training, English teachers were more familiar with the position requirement of software companies and were clearer about the profession skill needed for software engineers.

Based on the training achievement and employment skill illustrated by University of Kent, we design a detailed professional skill scale of software engineer.

Table 1

Professional Skill Scale of Software Engineer

\begin{tabular}{|c|c|c|}
\hline \multirow{17}{*}{$\begin{array}{l}\text { Software English } \\
\text { communicative skill }\end{array}$} & \multirow{3}{*}{ Reading skill } & Able to search for and fix IT information very fast. \\
\hline & & Able to generalize and analyze IT passages. \\
\hline & & Able to efficiently classify and organize IT information. \\
\hline & \multirow{3}{*}{ Writing skill } & $\begin{array}{l}\text { Able to write IT report with concise IT terms and clear logic, familiar with the } \\
\text { industry standard of IT writing. }\end{array}$ \\
\hline & & Able to describe and illustrate IT problems. \\
\hline & & $\begin{array}{l}\text { Able to express yourself clearly in writing and know how to design IT working } \\
\text { files. }\end{array}$ \\
\hline & \multirow{3}{*}{ Listening skill } & Able to grasp note-taking skills and draw charts with the heard information. \\
\hline & & Able to list key points in IT speeches and lectures. \\
\hline & & Able to analyze the listening passages and summarize main ideas. \\
\hline & \multirow{5}{*}{ Communicative skill } & Able to give a speech regarding the project design and project process. \\
\hline & & Able to apply technology to give a speech. \\
\hline & & $\begin{array}{l}\text { Able to communicate logically and clearly, choosing the different techniques } \\
\text { appropriate to occasions and situations. }\end{array}$ \\
\hline & & Able to adapt speeches according to different audience. \\
\hline & & Able to explain, negotiate, and debate IT issues. \\
\hline & \multirow{3}{*}{ Translation skill } & Able to translate IT working files. \\
\hline & & Able to explain information related to IT. \\
\hline & & Able to grasp IT English register, and its usage. \\
\hline \multirow{6}{*}{$\begin{array}{l}\text { Engineering thinking } \\
\text { habit }\end{array}$} & \multirow{4}{*}{ Skill of design the plan } & Able to conduct need-analysis. \\
\hline & & Creative, with unique perspective. \\
\hline & & $\begin{array}{l}\text { Able to conduct information collecting and statistics analysis (interview, } \\
\text { questionnaire). }\end{array}$ \\
\hline & & Able to design interface of software. \\
\hline & \multirow[b]{2}{*}{ Problem-solving skill } & Able to make full use of internet. \\
\hline & & $\begin{array}{l}\text { Able to discover problems in development and use of software and find out a } \\
\text { suitable solution. }\end{array}$ \\
\hline
\end{tabular}


(Table 1 continued)

\begin{tabular}{|c|c|c|}
\hline \multirow{2}{*}{$\begin{array}{l}\text { Engineering thinking } \\
\text { skill }\end{array}$} & \multirow{2}{*}{$\begin{array}{l}\text { Knowledge of software } \\
\text { engineering }\end{array}$} & Able to know about IT project parts, confirm the feasibility, plan the steps. \\
\hline & & $\begin{array}{l}\text { Able to grasp basic knowledge of software engineering, including coding, } \\
\text { design, testing, and maintenance. }\end{array}$ \\
\hline \multirow{5}{*}{$\begin{array}{l}\text { Emotion Quotient to } \\
\text { deal with problems }\end{array}$} & \multirow{3}{*}{$\begin{array}{l}\text { Team spirit and } \\
\text { communicative skill }\end{array}$} & Able to communicate effectively with partners on software issues. \\
\hline & & $\begin{array}{l}\text { Able to be clear about one's role and hold responsibilities in designing and } \\
\text { developing solutions to problems. }\end{array}$ \\
\hline & & Possessing organizing and cooperating skill. \\
\hline & \multirow{2}{*}{ Self-assessment skill } & Possessing autonomous learning skill. \\
\hline & & Possessing the skill of self-controlling and supervising study. \\
\hline
\end{tabular}

\section{Promotion of Project-Based Learning Aimed at Professional Skills}

\section{Project-Based Learning}

Project-based learning is a pedagogy which involves students in the project by providing an authentic problem. The original idea is promoted by John Dewey through his concept of "learning by doing", which stresses constructive activities. Blumenfeld, Soloway, Marx, Krajcik, Guzdial, and Palinscar (1991) elaborate on the processes of PBL based on constructivism:

Students pursue solutions to nontrivial problems by asking and refining questions, debating ideas, making predictions, designing plans and/or experiments, collecting and analyzing data, drawing conclusions, communicating their ideas and findings to others, asking new questions, and creating artifacts. (p. 369)

\section{Researches on Project-Based Learning}

Some researchers point out the merit of launching project-based learning. Hsiao (1997) considers it to be the effective way to help realize imagination and creativity, converting knowledge into abilities to cope with the challenges of life and work. Blumenfeld and Krajcik (2006) have demonstrated that students in project-based learning classrooms get higher scores than students in traditional classroom. Faridah Musa, Norlaila Mufti, Rozmel Abdul Latiff, and Maryam Mohamed Amin (2011) believe that project-based learning can promote language learning. Mahachart Inthachot, Saroch Sopeerak, and Nattaphon Rapaic (2013) think that project-based learning in mobile environment can improve creativity. In China, CAI Ji-gang (2012) has strongly advocated the ESP course pattern on the basis of need analysis. WANG Hui-ting (2014) has put project-learning in the ESP context. Our research attempts to carry out EOP project learning oriented at improving professional skill.

\section{Practice of EOP Project}

The overall goal of EOP program in our Software Department is to improve a mix of communicative and professional competence, achieve the mastery of a profession for the sake of promotion in one's position. EOP project provides vocational situations to fit for the position of software engineer, in which students can communicate with each other by using English as working language. Their professional skills are designed to be greatly developed in the project.

Students are wholly involved in five stages of project of making software: need requirement analysis, designing interface, coding, software testing, and software maintenance. Through the project-based learning, students are hoped to propose more grounded and realistic solutions to the problems occurring in the EOP project. Students concentrate on setting up and carrying out the projects, organizing their ideas, delegating 
responsibilities, negotiating overlapping roles, and monitoring their own progress. With their attention on completing the projects, language became a tool instead of a product in itself (Yogman \& Kaylani, 1996).

\section{Survey on the Professional Skills}

We conduct a survey to 162 EOP students. The result shows that efforts to do project in EOP program were not uniformly successful. Some of the lower level students in English and software are reported to have gained little. Therefore, suggestions on different EOP courses for different level students are made.

\section{Conclusion}

Students have admitted the growth of importance of the English language knowledge for getting a job. The output of the course will be measured against the standards that are established by English teachers and by a set of competences required by software engineering certification as approved by the Ministry of Education. EOP practitioners in our department are greatly encouraged to be engaged in the relevant research to enhance the campus prestige of the discipline. The sustainability of EOP project will be continuously supported by the department and creative atmosphere of project will contribute to the overall foreign language teaching system.

\section{References}

Blumenfeld, P. C., Soloway, E., Marx, R. W., Krajcik, J. S., Guzdial, M., \& Palinscar, A. (1991). Motivating project-based learning: Sustaining the doing, supporting the learning. Educational Psychologist, 26(3-4), 369-398.

Blumenfeld, P., \& Krajcik, J. (1994). Project based learning. In R. K. Sawyer (Ed.), The Cambridge handbook of the learning sciences. New York: Cambridge University Press.

CAI, J. G. (2012). College EOP course pattern research based on need analysis. English Teaching, 3, 47-50.

Hsiao, H. C. (1997). The improvement of creativity and productivity of technical workers through partnership between university and industry. Paper Presented at The International Conference on Creativity Development in Technical Education and Training, Taipei.

Inthachot, M., Sopeerak, S., \& Rapaic, N. (2013). The development of a U-learning instructional model using project based learning approach to enhance students' creating-innovation skills. Procedia Social and Behavioral Sciences, 103, 1011-1015.

Millrood, R. (2014). Teaching English to engineers at a tertiary level in Russia. Procedia Social and Behavioral Sciences, 154, 199-203.

Musa, F., Mufti, N., Latiff, R. A., \& Amin, M. M. (2011). Project-based learning: Promoting meaningful language learning for workplace skills. Procedia Social and Behavioral Sciences, 18, 187-195.

WANG, H. T. (2014). Application of project-based learning in EOP Teaching. China EOP Research, 5, 38-45.

What are the top ten skills that employers want? (n.d.). Retrieved from http://www.kent.ac.uk/careers/sk/top-ten-skills.htm

Yogman, J., \& Kaylani, C. T. (1996). EOP program design for mixed level students. English for Specific Purposes, 15(4), 311-324. 